УДК 82.035

ББК $83+83.3(0) 3$

ФИЛОЛОГИЧЕСКИЙ ПЕРЕВОД: ПРОБЛЕМЫ И ПЕРСПЕКТИВЫ (ИЗ ОПЫТА ПЕРЕВОДА ДРЕВНЕАНГЛИЙСКИХ ПЕРЕЛОЖЕНИЙ БИБЛИИ «ИСХОД» И «ДАНИИЛ»)

(C) 2019 г. М.В. Яценко

Санкт-Петербургский государственный университет телекоммуникаций им. проф. М.А. Бонч-Бруевича, Санкт-Петербург, Россия Дата поступления статьи: 3г октября 2018 г. Дата публикации: 25 марта 2019 г.

DOI: I0.22455/2500-4247-20I9-4-I-IO-27 Исследование выполнено при поддержке РГНФ, проект №ㄴ-04-50о82 а (ф)

Аннотация: Цель статьи - описать специфику филологического перевода как основного типа перевода древних текстов на современные языки. Анализ производится на материале переводов текстов древнеанглийских поэтических переложений Библии. В ходе анализа обосновывается необходимость использования филологического перевода как наиболее адекватного для данного типа текста, рассматриваются основные этапы действий филолога и переводчика, специфика передачи стилистических особенностей исходного текста. Описывая филологический перевод, автор сравнивает его с буквальным переводом, выделяя сходства и различия. Выделяются этапы перевода. Особое внимание в статье уделено специфике передачи стилистических средств исходного текста в русском переводе. При этом отмечается, что важную роль в создании перевода играет учет специфики его восприятия современным читателем сквозь призму поэтической традиции прошедших эпох. Существенной составляющей филологического перевода древнеанглийских переложений Библии являются предисловия и развернутые комментарии как лингвистического, так и культурологического и богословского плана, позволяющие проникнуть в суть текста.

Ключевые слова: этапы перевода, художественный перевод, филологический перевод, древнеанглийская поэзия, библейские парафразы, древнеанглийские поэмы «Исход» и «Даниил», эквилинеарный перевод.

Информация об авторе: Мария Вадимовна Яценко - кандидат филологических наук, доцент, Санкт-Петербургский государственный университет телекоммуникаций им. проф. М.А. Бонч-Бруевича, пр. Большевиков, д. 22, корп. I, I93232 г. СанктПетербург, Россия.

E-mail: toma345@yandex.ru, yatsenm@mail.ru

Для цитирования: Яиенко М.В. Филологический перевод: проблемы и перспективы (из опыта перевода древнеанглийских переложений Библии «Исход» и «Даниил») // Studia Litterarum. 2019. Т. 4, № I. С. IO-27.

DOI: I0.22455/2500-4247-20I9-4-I-IO-27 


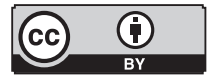

This is an open access article distributed under the Creative Commons Attribution 4.0 International (CC BY 4.O)

\section{PHILOLOGICAL TRANSLATION: PROBLEMS AND PERSPECTIVES (ON THE TRANSLATION OF THE OLD ENGLISH PARAPHRASES OF EXODUS
AND DANIEL INTO RUSSIAN)}

(C) 2019. M.V. Yatsenko

M.A. Bonch-Bruevich St. Petersburg

State University of Telecommunications,

St. Petersburg, Russia

Received: October 31, 2018

Date of publication: March 25, 2019

Acknowledgements: The research was financially supported by the Russian State Fund for Humanities, project №16-04-50082 a(f).

Abstract: The aim of the essay is to describe the specificity of the so called philological translation as the main technique applied to the translation of the ancient texts into modern languages. The article focuses on the translation of Old English poetic paraphrases of the Bible into Russian. The analysis justifies the necessity of using philological translation to translate such texts. It describes the main stages of translation process as well as the specificity of conveying stylistic peculiarities of the original text, paying special attention to the stylistic effects of the Old English poetry and its counterparts in the Russian verse. The essay stresses the role of the modern perspective and the poetical tradition of the past that should be taken into account by a translator of such texts. The indispensable parts of the philological translation are introductions and extensive commentary on the linguistic, cultural, and religious aspects of the translated texts that provides its better understanding.

Keywords: stages of translation, artistic translation, philological translation, Old English poetry, biblical translations, Old English poems Exodus and Daniel, equilinear translation.

Information about the author: Maria V. Yatsenko, $\mathrm{PhD}$ in Philology, Associate Professor, M.A. Bonch-Bruevich St. Petersburg State University of Telecommunications, 22/I Prospect Bolshevikov, 193232 St. Petersburg, Russia.

E-mail: toma345@yandex.ru, yatsenm@mail.ru

For citation: Yatsenko M.V. Philological Translation: Problems and Perspectives (On the Translation of the Old English Paraphrases of Exodus and Daniel into Russian). Studia Litterarum, 2019, vol. 4, no I, pp. IO-27. (In Russ.)

DOI: 10.22455/2500-4247-2019-4-I-IO-27 
Соображения, представленные в этой статье, - результат работы над переводами двух древнеанглийских поэтических переложений Библии, поэм «Исход» и «Даниил» на русский язык. Оба эти текста, как и подавляющее большинство текстов древнеанглийской поэтической традиции, записанных в VIII-XI вв., отражают общие эстетические принципы средневековой христианской культуры и национальную англосаксонскую специфику, которые мало понятны человеку новейшего времени. Своеобразие этой традиции и ее восприятие в современном мире определяют круг переводческих проблем, которые можно в самом общем плане сформулировать следующим образом: І) выбор типа перевода; 2) проблема передачи стилистического своеобразия текстов, относящихся к иной, давно ушедшей эстетической системе. Поскольку мы будем рассматривать переводческую работу изнутри, то подробнее остановимся на переводе как процессе, результат которого зависит от прохождения определенных этапов .

Проблема перевода древних текстов в переводоведении обсуждалась сравнительно мало, хотя переводчики с ней сталкивались всегда [12]. Тексты отдаленных исторических эпох вызывают интерес, главным образом, у специалистов или людей, готовых приложить определенные усилия для их понимания. Вдвойне это относится к текстам древнеанглийских парафраз Библии, которые представляют собой особый тип перевода. Для их воспроизведения средствами современного языка необходимо очень бережное сохранение стилистического своеобразия в самом широком смысле, т. е. ос-

I Проблема описания перевода как процесса стоит достаточно остро, как отмечает P.P. Чайковский, поскольку теория художественного перевода до сих пор сильно расходится с его реальностью [20, с. 25]. 
новных приемов и самой манеры изложения. В данном случае едва ли адекватным может быть ознакомительный перевод. Современному читателю, знающему содержание соответствующих библейских книг, безусловно, интересны прежде всего средства, которые использованы для его изложения и сама специфическая для древнеанглийской традиции манера изложения.

Наиболее адекватным для текстов этого типа является филологический перевод², который сохраняет в большинстве случаев дословность и эквилинеарность ${ }^{3}$ но предполагает ясность и выразительность. Неотъемлемым атрибутом такого перевода является так называемый «гипертекст»4, включающий в себя оригинальный текст, варианты перевода, подстрочные комментарии и комментарии к общему содержанию и стилю текста. Адресат такого перевода получает подробную (а в ряде случаев - почти исчерпывающую) информацию о тексте, истории и принципах его создания. Он готов потратить определенное время и силы на глубокое, «медленное» прочтение текста, чтобы ознакомиться со всем, что «стоит за текстом». Создатель перевода и комментариев должен учитывать, что эта работа читателя достаточно сложна. Восприятие самого текста и комментариев не следует затруднять искусственно. Важным при этом является учет эстетического воздействия оригинала. В случае с комментированным филологическим переводом переводческое решение, выбор определенного варианта происходит как бы «на глазах» читателя. Комментарии, которые включают и подстрочные дословные варианты, позволяют читателю стать соучастником перевода, увидеть часть подготовительного этапа работы переводчи-

2 Нам близко понимание термина «филологический перевод», представленное в работе А. Десницкого в связи с переводами Библии: «Филологический или научный перевод призван максимально отразить все черты оригинала, и содержательные, и формальные, чтобы читатели, не владеющие в достаточной мере языком оригинала, приблизились к нему насколько это возможно... Перевод должен быть ясен в той же мере, что и оригинал: так, все трудности и двусмысленности, с которыми сталкивался гипотетический первоначальный читатель, должны быть сохранены... Такой перевод, рассчитанный на внимательного и образованного читателя, может содержать примечания разного рода, куда будут внесены все разночтения с критическим текстом, альтернативные толкования, а также дословное значение туманного оборота речи, который был переведен буквально» [6, с. 2І2-2І3].

3 Эквилинеарность в данном случае понимается как воспроизведение словесного наполнения каждой конкретной строки оригинала в переводе.

4 Современные информационные технологии позволяют представить сводные издания критических статей и переводов древних памятников на одной Интернет-странице. Например, таких памятников, как «Беовульф», «Слово о полку Игореве» [9; 2г]. 
ка и «включиться» в нее. Цель филологического перевода - предоставить читателю наибольшее количество информации о тексте и воссоздать его на родном языке таким образом, который бы давал четкое представление о стилистических особенностях оригинала, не затрудняя его понимания.

Понятно, что все сказанное выше представляет собой идеальную модель филологического перевода. Каждый переводчик в той или иной мере приближается к ней, причем оценить, насколько хорошо это у него получается, может только читатель перевода. Рассматривая ситуацию с точки зрения переводчика, мы постараемся описать основные проблемы, с которыми нам пришлось столкнуться в процессе перевода, а также основные этапы перевода.

В создании филологического перевода можно выделить следующие основные этапы: г) первичное знакомство с текстом; 2) формулировка подстрочного перевода; 3) написание подробных комментариев и вариантов перевода; 4) художественная обработка текста; 5) редактирование перевода и комментариев.

На первом этапе (знакомство с текстом) необходимо осуществить подготовительную работу. Здесь важно выбрать литературу, характеризующую эпоху, текст и его содержание, сравнивающую тексты одной традиции. Важнейшим на этом этапе можно назвать поиск качественного издания текста: достаточно авторитетного, полного, с подробными комментариями. К такого рода классическим работам можно отнести издание «Беовульфа» Ф. Клэбера [27] и «Исхода» Э.Б. Ирвинга [зо]. Подробнейшие комментарии со ссылками на огромное количество источников, как и академичное предисловие к тексту, могут быть излишне обширными для начального этапа.

Фактически поиск авторитетного издания относится уже ко второму этапу работы, цель которого - составить подстрочник, отражающий хотя бы один вариант прочтения текста. В процессе создания подстрочника в сознании переводчика-филолога должен появиться вполне обозримый текст, с которым ему предстоит работать. В случае с древнеанглийской поэзией, как и с большинством древних текстов, возможность вариативного прочтения на первом этапе может стать деструктивным моментом. Важно «не утонуть» в вариантах. Чисто технически свои записи надо организовать таким образом, чтобы они отражали не только основной результат этого этапа - подстрочный перевод, но и процесс его создания - грамматический анализ текста. Поскольку переводчик берет на себя труд уточнения грамматического зна- 
чения каждого слова, важно, чтобы происходила фиксация всех возможных грамматических вариантов. При этом имеет смысл выделять тот вариант, который переводчик выбрал как основной. Как только подстрочник становится вполне понятным и читаемым текстом, время начального знакомства проходит, пора переходить к основной части филологической работы.

Здесь начинается время справочников и научной литературы. Невольно вспоминаешь слова С.С. Аверинцева о том, что филолог должен «знать о тексте все» [I, с. Іоо]. В случае с древнеанглийскими текстами в понятие «все» входят: точные данные о грамматике, семантике, археологии, англосаксонской истории, библейской истории и истории истолкования Библии до англосаксонского периода включительно. В целом, конечно же, здесь необходима целенаправленность действий, поскольку такого рода работа может быть бесконечной. Постановка определенных целей (например, прокомментировать текст или его фрагмент) здесь необычайно полезна. Когда удовлетворен всякого рода интерес относительно текста и его реалий, часто наступает охлаждение или ощущение, сравнимое с ощущением сытости. Хорошо, если это состояние пришло не только от прочтения справочной литературы и простого накапливания информации, но и от ее осмысления, когда вся эта кропотливая работа вылилась в серию статей и комментариев, посвященных разным аспектам текста, когда найдены и освоены источники, в которых одна и та же проблема рассмотрена с разных позиций.

Следующий этап перевода - создание художественного текста. Филологи часто препоручают этот этап профессиональному поэту-переводчику. Однако те, кто занимался художественными переводами текстов самостоятельно, в какой-то момент понимают, что именно эта деятельность и является самой приятной частью их труда5. В случае с переводчиком-филологом, который сам создает подстрочный перевод и комментарий и осознает ценность каждого слова оригинала, процесс выбора того или иного варианта (необходимый при создании художественного перевода) может оказаться болезненным. Очень часто тексты, подстрочники которых составлены, так и не обретают художественного оформления, потому что филолог либо не имеет возможности отдать текст профессиональному переводчику, либо не реша-

5 «Я никогда прежде не думал, что переводить так увлекательно: не понимаю, почему я оставлял эту работу для других», - признавался в конце жизни М.И. Стеблин-Каменский (цит. по: [15, с. го]). 
ется что-либо менять в подстрочном переводе сам. Создание художественно оформленного перевода возможно только в том случае, если филолог сможет ощутить эстетические недостатки подстрочного перевода. Здесь все зависит от художественного вкуса филолога и от того, насколько он может абстрагироваться от текста. Абстрагирование и способность выступить в качестве создателя художественного перевода у филолога могут быть замедлены в силу своеобразного «преклонения» перед текстом оригинала. Действительно, вся подготовительная филологическая работа предполагает чрезвычайно бережное отношение к исходному тексту, стремление понять и сохранить его как можно более точно. В данной ситуации переход филолога к переводческой работе может быть стимулирован следующими важнейшими моментами: I) понимание недостатков имеющегося подстрочного перевода и 2) осмысление преимуществ художественной формы оригинала и необходимости передачи этой формы средствами, понятными потенциальному читателю.

На этапе создания художественного текста необходимо начать воспринимать подстрочный перевод как вспомогательное средство. Это особенно сложно, поскольку подстрочный перевод во многом близок переводу филологическому: он также передает формальные особенности оригинала. Однако нельзя забывать, какое впечатление он может произвести на случайного читателя. Оно очень точно сформулировано Н. Заболоцким: «Подстрочник поэмы подобен развалинам Колизея. Истинный облик постройки может воспроизвести только тот, кто знаком с историей Рима, его бытом, его обычаями, его искусством, развитием его архитектуры. Случайный зритель на это не способен» [7, с. 252]. Очень похожее впечатление может производить и перевод буквальный или буквалистический. Цель буквального перевода в его утрированном понимании - показать индивидуальность каждой культуры, ее неповторимость и в конечном счете непереводимость ${ }^{6}$. Буквальный перевод, возведенный в разряд эстетического принципа, отрицает саму возможность понимания текста перевода, лишая его потенциального адресата. Такой взгляд на перевод во многом отменяет возможность и необходимость реализации основной цели работы переводчика - обеспечения взаимопонимания и диалога культур. Однако буквалистичность как один из переводческих приемов, предполагающий использование максимально ко- 
роткой «длины контекста», в случае с древними текстами неизбежен. Близки и задачи буквального и филологического переводов - более тесное и близкое знакомство адресата перевода с реалиями языка-источника. Однако цель филологического перевода - прояснить текст (в том числе за счет вспомогательных средств, таких как примечания и комментарии). Другим способом обеспечения понятности текста является создание определенного эмоционального впечатления, которое должно отражать художественные особенности оригинала и способствовать более глубокому его пониманию. Воздействие подстрочного и филологического перевода мы попытаемся наглядно продемонстрировать на примере отрывка из поэмы «Исход»: «рær [forð] æfter him/ folca pryðum// sunu Simeones/ sweotum common,// pridde peodmægen/ (pufas wundon// ofer garfare)/ guðcyste onprang// deawig sceftum./» (Ex 340-3447). В подстрочном переводе он выглядел так: «Тогда вслед за ним / толпы племен // потомки Симеона, / отрядами пошли, // третий могучий род / (флаги вились // над движущимся войском с копьями), / вся армия шла вперед, // покрытая росой, с древками копий./». В филологическом переводе: «Там вослед ему / другого племени род, // Симеона сыны, / строем ступали, // третье племя могучее. / Флаги реяли // над шествием войска копейного, / вперёд устремлённого // росистой ратью./».

При переводе древних текстов проблема воспроизведения стилистических особенностей оригинала оказывается тесно связана с осмыслением их художественных достоинств. При использовании в переводе того или иного стилистического приема необходимо найти и отразить прежде всего ту его сторону, которая и в наши дни воспринималась бы как достоинство. Стиль древнеанглийской поэзии значительно отличается от поэзии современной. Сам способ ее существования предполагал ориентацию на устное восприятие ${ }^{8}$, потому текст каждый раз пересоздавался в процессе его исполнения9. Современный перевод записанного текста никогда не будет адекватен исходному тексту прежде всего в силу изменения способа существования поэзии.

Одной из важнейших характеристик текстов, предназначенных для устного исполнения, является большое количество устойчивых формульных

7 Текст приводится по изданию [3о]. Перевод был опубликован в [22; 23; 24; 25; 26].

8 Как основа понимания средневековой поэзии именно этот принцип предлагается в: [8].

9 Сочинение в процессе исполнения - основная идея теории «неосознанного авторства» М.И. Стеблин-Каменского [I7], а также устно-формульной теории [II]. 
выражений ${ }^{\text {Iо }}$ В эстетике современной литературы формульные, стандартные выражения воспринимаются во многом как недостаток ${ }^{\text {II }}$. Тогда как литература древности (в большинстве своем) использует именно традиционные средства, а повторяемость является неотъемлемой частью ее эстетики [3I]. Воспроизводя формульные выражения в переводе, переводчик повторяет принципы организации древнеанглийского текста, однако не может передать специфику их эстетического воздействия. Восприятие формульных выражений в живой устной традиции сопряжено с их припоминанием. Носители этой традиции использовали одну и ту же формулу в разных текстах или на протяжении одного и того же текста. Участие формул в интертекстуальном взаимодействии - это тот аспект, который можно передать в переводе только целого корпуса текстов. При внимательном рассмотрении отдельных древнеанглийских поэм оказывается, что в разных текстах формулы работают по-разному. В поэме «Исход» формульные выражения повторяются редко, чаще воспроизводятся формульные (синтаксические) модели, появление которых в переводе не всегда заметно. Такого рода формульность не «обедняет» текст в современном понимании. Текст поэмы «Даниил», хотя и следует за «Исходом» в рукописи, и записан той же рукой, демонстрирует совершенно иной принцип использования формул. «Даниил» содержит ряд повторяющихся (типичных) сцен, где используются схожие модели и обороты. Среди них выделяются не столько формулы (устойчивые словосочетания), сколько схожие предложения. Например, фразы, повторяющиеся при описании речевых эпизодов. Так, поэт использует предложение: «ра him unbliðe / andswaredon» - «Тогда ему несчастные / отвечали» (Dan I2722) в поэме дважды на протяжении девяти строк. Сначала для описания действий прорицателей (Dan I27), которых царь Навуходоносор просит отгадать значение его сна, а затем эта же фраза, но с глагольной формой единственного числа обозначает и действия самого царя (Dan I34). Использование однотипной конструкции на небольшом промежутке текста создает впечатление однообразности жизни Навуходоносора и его придворных, которые названы «несчастными»,

Iо Это свойство характерно как для древнеанглийской [4], так и для других средневековых литератур [8].

II Д.С. Лихачев писал о том, что в главным отличием современной литературы от литературы древней является стремление к «преодолению “автоматизма” [го].

I2 Здесь и далее текст поэмы «Даниил» цитируется по изданию [28] с переводом автора статьи и указанием в скобках номера строки. 
«не блаженными» (unbliðе). В дальнейшем схожая формула описывает действие пророка Даниила, который назван (в противовес царю и его мудрецам) сведущим в законе: «Him æcræftig / andswarode» - «Им в законе сведущий / ответствовал» (Dan 74I). Прием повторяемости здесь используется для сравнения действий разных героев. Таким образом, он обретает стилистическую окраску, которая могла восприниматься как новшество в древнеанглийской традиции. Но в поэтике современной и в переводе она выглядит как нечто совершенно тривиальное. Широкое использование такого рода традиционных приемов в поэме «Даниил» делает ее в глазах современного читателя менее интересной и красочной. Кажется, что она лишена типично германского духа и большой доли оригинальности, которая присуща «Исходу» и «Беовульфу».

Принцип повторяемости реализуется в древнеанглийском тексте и в таком важном нарративном приеме, как эпическая вариация, предполагавшем повторные наименования одного объекта. При этом используются обширные синонимические ряды простых и сложных наименований. Вполне естественно воспринимаются вариации в Песне трех отроков из поэмы «Даниил», где несколько раз именуется Бог и все его творения. Хотя специфика исходного текста, где всякий раз повторяется одно и то же наименование Бога, меняется в древнеанглийской версии, сам жанр хвалебной песни ассоциируется с нанизыванием рядов наименований. Но в древнеанглийской традиции этот прием характерен и для описательного повествования. Например, при рассказе о Ное в поэме «Исход» появляется ряд наименований живых существ, которые оказались в ковчеге. В конце этого ряда вдруг появляется наименование «мудрый мореход», которое, вероятно, относится к самому Ною: «On feorhgebeorh / foldan hæfde // eallum eorðcynne / есе lafe, // frumcneow geh[w]æs, / fæder and moder // tuddorteondra, / geteled rime // missenlicra / ponne men cunnon, // snottor sæleoda» - «Для сохранения жизни / с суши он взял, // из каждого рода земного / в вечное наследство // первородителей, / отца и матерь, // родоположников; / отсчитанное число // от каждой твари, / от тех, что люди ведали, // мудрый мореход» (Ex 369-374). При чтении таких фрагментов современный читатель в ряде случаев как бы утрачивает логику повествования, которое строится как описание отдельных картин ${ }^{\mathrm{1}}$. При филологическом переводе такого рода фрагмен-

I3 Такую технику повествования сравнивают с описанием застывших изображений (совр. англ. stills) [29]. 
ты не поддаются сокращению, способствовать их адекватному восприятию может только комментарий или перестановка членов вариации. Последний прием, однако, приведет к нарушению принципа эквилинеарности.

Наиболее яркой стороной перевода эпической вариации является потребность передать все богатство синонимических возможностей поэтического языка. Например, в древнеанглийском поэтическом словаре существовало около двадцати простых наименований моря, большая часть которых могла использоваться в огромном количестве составных наименований. Подобного рода богатство синонимии наблюдается у наименований воина, мужа, военных доспехов, битвы и пр. В переложениях Библии появляется и масса самых разных наименований Бога. В переводе на русский язык расширение словарного объема возможно за счет возвышенной лексики, церковнославянизмов, устаревших слов. Совмещение этих слоев лексики вполне органично для русской поэтической традиции. Более того, оно соответствует тематике исходного текста: церковнославянизмы (помимо архаизации) позволяют передать возвышенность описываемых реалий, их связь с сакральной сферой. При переводе древнеанглийского текста на современный английский язык проблема архаизации стоит значительно острее: большая часть возвышенной лексики современного английского языка имеет не древнеанглийское, а романское происхождение [I4, с. I75]. Преимущество русского переводчика в данном случае очевидно. Элементы архаики дошли прямо или косвенно до наших дней за счет непрерывности русской литературной традиции и органичного существования в ней церковнославянизмов. Этот словесный материал ценен еще и тем, что он отражает не только конкретные реалии, но и огромный опыт русской литературы ${ }^{14}$. Однако богатство русской лексики возвышенного стиля имеет и оборотную сторону: устаревшие слова часто имеют яркую национальную окраску. При переводе часто возникает вопрос о том, какое наименование, например, воина можно употребить в переводе древнеанглийского текста: «воитель», «витязь», «эрл»? Не имеет ли второе ярко выраженной национальной окраски? Использование этого слова в переводах грузинской поэмы («Витязь в тигровой шкуре») в определенном смысле делает этот вопрос менее острым, однако подобного рода традиция освоения лексем с национальной окраской в переводах - скорее исключе- 
ние. И проблема эта касается не только устаревших слов, но и общеупотребительных. Можно ли, например, использовать в переводе древнеанглийского текста слово «армия»? Со строго исторической точки зрения, к англосаксонским воинам, видимо, относить это слово не вполне логично. А как быть, когда англосаксы описывают не свое собственное, а египетское и израильское воинство? Или когда в центре внимания войско императора Константина (поэма «Елена»), которое, вероятнее всего, и называлось армией. Слишком сильные современные ассоциации этого слова, как и позднее время его заимствования русским языком ${ }^{15}$, не дают возможности употребить его в переводе древнеанглийской поэзии, хотя оно и является стилистически нейтральным.

Проблема выбора подходящего слова в ряде случаев может быть решена при помощи так называемых «потенциальных» слов ${ }^{16}$ («воитель», «добропобедный» и др.). Такие слова, как бы создаваемые в процессе рассказа, чаще всего не имеют связи с определенными реалиями принимающей культуры. За счет использования такого рода лексики В.Г. Тихомирову удалось создать неповторимый колорит англосаксонской поэзии в русском переводе. Пытаясь следовать его примеру, мы всякий раз находили вновь создаваемые «потенциальные» слова в подробнейшем Словаре живого великорусского языка В.И. Даля [5]. Само чтение этого словаря в ряде случаев облегчало принятие переводческих решений. Алфавитно-гнездовой способ организации лексики в Словаре дает возможность увидеть сразу все варианты употребления корня и оттенки его значения. В целом, такой тип словаря дает то самое представление о безграничности возможностей языка, которое создается и при чтении древних текстов, в том числе древнеанглийской поэзии. Поскольку Словарь обладает и гораздо более богатыми запасами, чем те, которые можно использовать для перевода древнеанглийской поэзии, главным критерием выбора лексики была понятность, «прозрачность» внутренней формы слова. Среди таких слов можно выделить, например, «родоположник» (др.-англ. tuddorteonde), «воевода сопутный» (др.-англ. siðboda), «Жизнеподатель» или «Живоначальный» (др.-англ. Liffrea).

Другой яркой стилистической особенностью древнеанглийского поэтического текста является своеобразие его ритмического устройства. Оно

I5 Заимствовано из немецкого или французского в начале XVIII в. [I9].

I6 Этот прием широко использовался в переводах В.Г. Тихомирова и описан О.А. Смирницкой [14]. 
значительно отличается от устройства современной поэзии. Поэтическая строка древнеанглийского текста строится на основе созвучия ударных корневых слогов, рифма, как и количество слогов в строке, не играет организующей роли. Это дает переводчику значительно больше свободы, чем в случае с рифмованной поэзией и силлабо-тоническим стихосложением. Поэтический текст с обилием аллитераций, отсутствием рифмы и большим количеством новых (или потенциальных) слов отчасти напоминает стихотворческие эксперименты Серебряного века. Это и словотворчество В. Хлебникова и футуристов, раннего Б. Пастернака, К. Бальмонта и других поэтов. Сама поэзия Серебряного века создала определенную поэтическую традицию, в некоторой степени подхваченную поэтами последующих поколений, на фоне которой попытка воспроизвести аллитерационный стих в наше время уже не выглядит как рискованный поэтический эксперимент. Выдвижение в стихах словесного созвучия на первое место [например, «Я клавишей стаю кормил с руки // Под хлопанье крыльев, плеск и клекот» (Б. Пастернак. Импровизация)], во многом раздвинуло наши представления о том, что такое стих. Этот прием заставил многих поэтов последующих поколений (в том числе и наших современников) использовать технику «звукописи» значительно чаще, чем это делали поэты золотого века. Освоение приема аллитерации в русском стихе позволяет экспериментировать с ним в переводе достаточно широко.

В древнеанглийском тексте аллитерация была основным приемом организации стиха. Она обладала и семантической нагрузкой, поскольку предполагала созвучие ударных корневых морфем (возможное в силу фиксированности ударения в германских языках), благодаря чему, по словам О.А. Смирницкой, поэт «оперирует не звуками < ..>, а созвучными знаками» [І6, с. 7I]. Точная передача акустических особенностей англосаксонской и шире - древнегерманской аллитерации на любом языке, не имеющем фиксированного корневого ударения, невозможна. Однако принцип созвучия слов как важнейший способ установления их «родства и свойства» остается неизменным. Аллитерация усиливается при появлении созвучия ударных слогов [например, в переводе поэмы «Исход»: «возвращение в вотчину / сыновей Авраамовых» (Ех I8), «десять сот сочли / достославных» (Ех 23I), «Волна ввысь вздымается, / вдруг соделает // струя стену защитную. / Стези просохнут - // седые прогоны ратные. / Море расступится» (Ex 282-284)]. Именно ритм ударных слогов как основа звуковой организации текста был 
использован в переводе В.Г. Тихомирова («Я в жизни не видывал / ладьи, оснащенной // лучше, чем эта, / орудьями боя, // одеждами битвы - / мечами, кольчугами...» [2]). Мы старались в переводе большей части строк сохранять именно принцип аллитерационного созвучия как основной.

Таким образом, стилистические приемы древнеанглийской поэзии далеко не всегда воспроизводимы средствами современного русского языка, что связано со спецификой эволюции поэтического стиля и языка. Процесс создания художественного перевода требует умения одновременно и впитать все сведения о тексте, и ощутить его художественное своеобразие.

При создании художественного текста переводчик переживает самый увлекательный этап работы, который предполагает принятие спонтанных решений. В.Г. Тихомиров выразил эту мысль следующим образом: «Никогда не делай того, что умеешь делать» [г8]. Это утверждение ни в коем случае не является оправданием непрофессионализма, не может оно значить и отрицания какой-либо логики или возможности научения переводу. В.Г. Тихомиров имел в виду именно элемент спонтанности и нестандартности мышления как основное умение переводчика.

Для окончательного оформления текста необходимо пройти еще один заключительный этап - редактирование перевода и комментариев. На этом этапе важно еще раз пережить абстрагирование от созданного текста, суметь взглянуть на него «со стороны» и организовать его в соответствии с нормами современного русского языка.

\section{Список литературы}

I Аверинцев С.С. Похвальное слово филологии // Юность. I969. № I. С. 99-І02.

2 Беовульф / пер. В.Г. Тихомирова, ред. и комм. О.А. Смирницкой // Беовульф. Старшая Эдда. Песнь о Нибелунгах. М.: Худож. лит., І975. С. 27-75.

3 Гаспаров M. Брюсов и буквализм (По неизданным материалам к переводу «Энеиды») // Мастерство перевода: сб. ст. М.: Сов. писатель, I97І. С. I04-Іо5.

4 Гвоздещкая Н.Ю. Семантика древнеанглийской поэтической формулы (на материале «Беовульфа» и «Видение Креста») // Лингвистика на рубеже эпох. Идеи и топосы. М.: РГГУ, 200I. С. 245-263.

5 Даль В.И. Толковый словарь живого великорусского языка: в 4 т. / под ред. И.А. Бодуэна де Куртенэ. М.: Прогресс, Изд. фирма «Универс», І994. 2030 стб. (Репринт. изд. І903-І909 гг.) 
Десницкий А. Современный библейский перевод: теория и методология.

М.: Изд-во ПСТГУ, 2015. 429 с.

Заболоцкий Н. Заметки переводчика // Мастерство перевода: сб. ст.

М.: Сов. писатель, І959. С. 25I-253.

8 Зюмтор П. Опыт построения средневековой поэтики / пер. с фр. И.К. Стаф. СПб.: Алтейя, 2003. 554 с.

Корпус переводов «Слова о полку Игореве». URL: http://nevmenandr.net/slovo/ (дата обращения: ог.09.20I8). Лихачев Д.С. Поэтика древнерусской литературы. М.: Наука, І979. 360 с. Лорд А.Б. Сказитель / пер. с англ. и комм. Ю.А. Клейнера и Г.А. Левинтона. М.: Издат. фирма «Восточная литература» РАН, г994. 368 с. Маркиш С. Несколько заметок о переводах с древних языков // Мастерство перевода: сб. ст. М.: Сов. писатель, І959. С. І53-г72.

I3 Рассадин Ст. Плюс десять веков // Мастерство перевода: сб. ст. М.: Сов. писатель, г97і. С. 55-87.

I4 Смирницкая О.А. Поэтическое искусство англосаксов // Древнеанглийская поэзия. М.: Наука, І982. С. І7І-232.

I5 Смирницкая О.А. Предисловие // Слово в перспективе литературной эволюции. К гоо-летию М.И. Стеблин-Каменского. М.: Языки славянской культуры, 2004. C. 9-I7. Смирницкая О.А. Стих и язык древнегерманской поэзии. М.: Филология, 1994. 226 с. Стеблин-Каменский М.И. Мир саги. Л.: Наука, І97І. І39 с.

I8 To, что умеешь делать, лучше не делать: Интервью с В.Г. Тихомировым. URL: http://old.russ.ru/krug/20030I22_kalash.html (дата обращения: ог.09.20I8). Фасмер М. Этимологический словарь русского языка: в 4 т. / пер. с нем. и доп. О.Н. Трубачева. М.: Терра-книжный клуб, 2008. Т. г. 573 с.

Чайковский Р.P. Реальности поэтического перевода (типологические и социологические аспекты) / отв. ред. Л.Л. Нелюбин. Магадан: Кордис, І997. 97 с. Энциклопедия «Слова о полку Игореве». URL: http://feb-web.ru/feb/slovo/default.asp (дата обращения: ог.09.20I8). Яценко М.В. Древнеанглийская поэма «Исход». Отрывок. Глава г / пер. с древнеангл. и коммент. M.В. Яценко // Cursor Mundi. Человек Античности, Средневековья и Возрождения. Научный альманах, посвященный проблемам исторической антропологии. Иваново: ИвГУ, 20I4. Вып. 6. С. І3І-І37. Яценко М.В. Древнеанглийская поэма «Исход» [Кэдмон? «Школа Кэдмона»?]. Главы II-IV / пер. и коммент. М.В. Яценко // Средние века. Исследования по истории Средневековья и раннего Нового времени. М.: Наука, 20I4. Вып. 75 (I-2). C. 255-26I.

24 Яценко М.В. Древнеанглийская поэма «Исход». Глава V / пер. с древнеангл. и коммент. М.В. Яценко // Cursor Mundi: человек Античности, Средневековья и 
Возрождения. Научный альманах, посвященный проблемам исторической антропологии. Иваново, 2016. Вып. 8. С. І28-г34.

25 Яценко М.В. Древнеанглийская поэма «Исход». Глава VI / пер. с древнеангл. и коммент. М.В. Яценко // Cursor Mundi. Человек Античности, Средневековья и Возрождения. Научный альманах, посвященный проблемам исторической антропологии. Иваново, 2015. Вып. 7. С. І74-182.

26 Яценко М.В. Древнеанглийская поэма «Исход» [Кэдмон? «Школа Кэдмона»?]. Глава VIII / пер. и коммент. М.В. Яценко // Вестник ПСТГУ. Серия Филология. 20I4. № 4. C. I54-I66.

27 Beowulf \& the Fight at Finnsburg / ed. by F. Klaeber, with introd., bibliography, notes, glos. and appendices. $3^{\text {rd }}$ ed. Boston: Heath \& co., I950. 4I2 p.

28 Daniel and Azarias / ed. with introd., notes and glos. by R.T. Farrell. London: Butler and Tanner, I974. I39 p.

29 Evans J.M. "Genesis B" and its Background // Review of English Studies. New Series. Vol. I4. P. II3-I23.

30 Exodus: Old English Exodus / ed. with introd., notes and glos. by E.B.Jr. Irving. New Haven, I953. I36 p.

3I Tyler E.M. Old English Poetics. The aesthetics of the familiar in Anglo-Saxon England. York: York Medieval Press, 2006. I98 p.

\section{References}

I Averintsev S.S. Pokhval'noe slovo filologii [The word of praise to philology]. Iunost', I969, no I, pp. 99-IO2. (In Russ.)

2 Beovul'f [Beowulf], transl. by V.G. Tikhomirova, ed. and comm. by O.A. Smirnitskoi. Beovul'f. Starshaia Edda. Pesn' o Nibelungakh [Beowulf. Elder Edda. Song of the Nibelungs]. Moscow, Khudozh. lit. Publ., I975, pp. 27-75. (In Russ.)

3 Gasparov M. Briusov i bukvalizm (Po neizdannym materialam k perevodu "Eneidy") [Brusov and literal principles in translation (On the unpublished translation of Aeneid)]. Masterstvo perevoda: sbornik statei [Translation skills. Collection of essays]. Moscow, Sov. pisatel' Publ., I97I, pp. I04-I05. (In Russ.)

4 Gvozdetskaia N.Iu. Semantika drevneangliiskoi poeticheskoi formuly (na materiale "Beovul'fa" i "Videnie Kresta”) [On the semantics of the Old English poetic formula (Beowulf and The Dream of the Rood)]. Lingvistika na rubezhe epokh. Idei i toposy [Linguistics at the turn of the era. Ideas and topoi]. Moscow, RGGU Publ., 200I, pp. 245-263. (In Russ.)

5 Dal' V.I. Tolkovyi slovar' zhivogo velikorusskogo iazyka: $v 4$ t. [Dictionary of the living Russian language: in 4 vols.], ed. by I.A. Boduena de Kurtene. Moscow, Progress, Izd. firma “Univers” Publ., I994. 2030 col. (In Russ.)

6 Desnitskii A. Sovremennyi bibleiskii perevod: teoriia i metodologiia [Modern Biblical translation: theory and methodology]. Moscow, Izd-vo PSTGU Publ., 20I5. 429 p. (In Russ.) 
Zabolotskii N. Zametki perevodchika [Translator's notes]. Masterstvo perevoda: sbornik statei [Translation skills. Collection of essays]. Moscow, Sov. pisatel' Publ., I959, pp. 25I-253. (In Russ.)

Ziumtor P. Opyt postroeniia srednevekovoi poetiki [Essay on the Medieval Poetics], transl. by I.K. Staf. St. Petersburg, Alteiia Publ., 2003. 554 p. (In Russ.) Korpus perevodov "Slova o polku Igoreve" [Corpus of the Translations of The Song of Igor's Campaign]. Available at: http://nevmenandr.net/slovo/ (Accessed or September 2018). (In Russ.) Likhachev D.S. Poetika drevnerusskoi literatury [Poetics of the Old Russian literature]. Moscow, Nauka Publ., I979. 360 p. (In Russ.) Lord A.B. Skazitel' [The storyteller], transl. and comm. by A. Kleinera, G.A. Levintona. Moscow, Izdatel'skaia firma “Vostochnaia literature” RAN Publ., I994. 368 p. (In Russ.) Markish S. Neskol'ko zametok o perevodakh s drevnikh iazykov [Some notes on the translations from ancient languages]. Masterstvo perevoda: sbornik statei [Translation skills. Collection of essays]. Moscow, Sov. pisatel' Publ., I959, pp. I53-I72. (In Russ.) Rassadin St. Plius desiat' vekov [Plus Ten Centuries]. Masterstvo perevoda: sbornik statei [Translation skills. Collection of essays]. Moscow, Sov. pisatel' Publ., I97I, pp. 55-87. (In Russ.)

I4 Smirnitskaia O.A. Poeticheskoe iskusstvo anglosaksov [The poetic art of Anglo-Saxons]. Drevneangliiskaia poeziia [Old English Poetry]. Moscow, Nauka Publ., I982, pp. I7I-232. (In Russ.)

Smirnitskaia O.A. Predislovie [Preface]. Slovo v perspektive literaturnoi evoliutsii. K Ioo-letiiu M.I. Steblin-Kamenskogo [On the perspective of literary evolution. To the Iooth anniversary of M.I. Steblin-Kamensky]. Moscow, Iazyki slavianskoi kul'tury Publ., 2004, pp. 9-I7. (In Russ.) Smirnitskaia O.A. Stikh i iazyk drevnegermanskoi poezii [The verse and the language of Old English poetry]. Moscow, Filologiia Publ., I994. 226 p. (In Russ.) Steblin-Kamenskii M.I. Mir sagi [The world of the saga]. Leningrad, Nauka Publ., I97I. I39 p. (In Russ.) To, chto umeesh' delat', luchshe ne delat': Interv'iu s V.G. Tikhomirovym ["Don't do what you know how to do": an interview with V.G. Tikhomirov]. Available at: http://old. russ.ru/krug/20030I22_kalash.html (Accessed or September 20I8). (In Russ.)

I9 Fasmer M. Etimologicheskii slovar' russkogo iazyka: $v 4 t$. [Etymological dictionary of the Russian Language: in 4 vols.], transl. by O.N. Trubacheva. Moscow, Terra-knizhnyi klub Publ, 2008. Vol. I. 573 p. (In Russ.) Chaikovskii R.R. Real'nosti poeticheskogo perevoda (tipologicheskie i sotsiologicheskie aspekty) [The practice of poetic translation (typological and sociological aspects)], ed. L.L. Neliubin. Magadan, Kordis Publ., I997. I97 p. (In Russ.) 
Entsiklopediia "Slova o polku Igoreve" [Encyclopedia of The Song of Igor's Campaign]. Available at: http://feb-web.ru/feb/slovo/default.asp (Accessed or September 20I8). (In Russ.)

Iatsenko M.V. Drevneangliiskaia poema “Iskhod”. Otryvok. Glava I [Old English poem "Exodus." The Passage. Chapter I], transl. from Old English and comm. by M.V. Iatsenko. Cursor Mundi. Chelovek Antichnosti, Srednevekov'ia i Vozrozhdeniia. Nauchnyi al'manakh, posviashchennyi problemam istoricheskoi antropologii [Cursor Mundi. Man of the antiquity, Middle Ages and Renaissance. Scientific almanac dedicated to problems of the historical anthropology]. Ivanovo, IvGU Publ., 20I4, issue 6, pp. I3I-I37. (In Russ.)

Iatsenko M.V. Drevneangliiskaia poema “Iskhod” [Kedmon? “Shkola Kedmona”?]. Glavy II-IV [Old English poem “Exodus”. [Caedmon? “The School of Caedmon”?]. Chapters II-IV], transl. from Old English and comm. by M.V. Iatsenko. Srednie veka. Issledovaniia po istorii Srednevekov'ia i rannego Novogo vremeni [Middle Ages. Studies in the history of the Middle Ages and Early Modern times]. Moscow, Nauka Publ., 20I4, issue 75 (I-2), pp. 255-26I. (In Russ.)

Iatsenko M.V. Drevneangliiskaia poema "Iskhod”. Glava V [Old English Poem “Exodus." Chapter V], transl. from Old English and comm. by M.V. Iatsenko. Cursor Mundi: chelovek Antichnosti, Srednevekov'ia i Vozrozhdeniia. Nauchnyi al'manakh, posviashchennyi problemam istoricheskoi antropologii [Cursor Mundi. Man of the antiquity, Middle Ages and Renaissance. Scientific almanac dedicated to the problems of historical anthropology]. Ivanovo, 2016, issue 8, pp. I28-I34. (In Russ.)

Iatsenko M.V. Drevneangliiskaia poema "Iskhod". Glava VI [Old English poem "Exodus." Chapter VI], transl. from Old English and comm. by M.V. Iatsenko. Cursor Mundi. Chelovek Antichnosti, Srednevekov'ia i Vozrozhdeniia. Nauchnyi al'manakh, posviashchennyi problemam istoricheskoi antropologii [Cursor Mundi. Man of Antiquity, Middle Ages and Renaissance. Scientific almanac dedicated to the problems of historical anthropology]. Ivanovo, 2015, issue 7, pp. 174-I82. (In Russ.)

Iatsenko M.V. Drevneangliiskaia poema "Iskhod" [Kedmon? "Shkola Kedmona”?]. Glava VIII [Old English poem "Exodus.” [Caedmon? “The School of Caedmon”?]. Chapter VIII], transl. from Old English and comm. by M.V. Iatsenko. Vestnik PSTGU. Seriia Filologiia, 20I4, no 4, pp. 154-I66. (In Russ.)

Beowulf $\mathcal{E}$ the Fight at Finnsburg, ed. by F. Klaeber, with introd., bibliography, notes, glos. and appendices. $3^{\text {rd }}$ ed. Boston, Heath \& co., I950. 4I2 p. (In English)

Daniel and Azarias, ed. with introd., notes and glos. by R.T. Farrell. London, Butler and Tanner, 1974. I39 p. (In English)

Evans J.M. "Genesis B" and its Background. Review of English Studies. New Series, vol. I4, pp. II3-I23. (In English)

Exodus: Old English Exodus, ed. with introd., notes and glos. by E.B.Jr. Irving. New Haven, 1953. 136 p. (In English)

Tyler E.M. Old English Poetics. The aesthetics of the familiar in Anglo-Saxon England. York, York Medieval Press, 2006. 198 p. (In English) 